Volume 4 No. 3 Juli 2019

p-ISSN: 2477-8192 dan e-ISSN: 2502-2776

\title{
PENGEMBANGAN OBYEK WISATA PANTAI KOGUNA TERHADAP PEREKONOMIAN MASYARAKAT DESA MOPAANO KECAMATAN LASALIMU SELATAN KABUPATEN BUTON
}

\author{
Novita Vivian ${ }^{1}$, La Ode Nursalam ${ }^{2}$ \\ ${ }^{1}$ Program Studi Pendidikan Geografi \\ Universitas Halu Oleo \\ Email: vivianadhybarta01@gmail.com \\ ${ }^{2}$ Program Studi Pendidikan Geografi \\ Universitas Halu Oleo \\ Email: vivianadhybarta01@gmail.com
}

(Received: 3 Mei 2019 ; Reviewed: 10 Mei 2019; Accepted: 7 Juli; Published: 8 Juli 2019)

(C2019 - Jurnal Penelitian Pendidikan Geografi. Ini adalah artikel dengan akses terbuka dibawah licenci CC BY-NC-4.0 (http://creativecommons.org/licenses/by-nc/4.0).

\begin{abstract}
Koguna Beach is a beach located in Mopaano Village which is the object of research because in this region the government is developing the beach tourism objectThe formulation of the problem in this study is (1) how the impact of tourism development on perekonomina (2) how the government efforts in developing tourism objects in Koguna Beach, Lasalimu Selatan District, Buton Regency. The purpose of this study (1) is to find out whether the development of Koguna beach tourism on the economy of the people of Mopaano Village South Lasalimu Subdistrict, Buton Regency (2) to find out how the government in developing Koguna beach tourism objects to the community income in Mopaano Village South Lasalimu Subdistrict Buton Regency. The method in this study is qualitative. Data collection techniques are observation, interview, documentation. The results of the study can be concluded that with the development of this tourism object, community income increases, community activities increase, the availability of employment opportunities, community welfare is very. The conclusion of this study (1) the development of this tourism object can have an impact on the economy of the community in Mopaano Village where the previous income was under Rp.1,000,000, after this development their income averaged over Rp.1,000,000; (2) government efforts to carry out development in tourism objects ranging from improving road access, construction of facilities and infrastructure to tourist attractions until the government will introduce this tourism object outside the region then the government will open sea transportation lines and will make this area an economic area creative.
\end{abstract}

Keywords: Impact of Development, Tourism Objects, Economy, Results

\section{ABSTRAK}

Pantai koguna merupakan pantai yang berada di Desa Mopaano yang menjadi obyek penelitian peneliti karena pada kawasan ini pemerintah melakukan pengembangan obyek wisata dipantai tersebut Rumusan masalah pada penelitian ini adalah (1)bagaimana dampak pengembangan obyek wisata terhadap perekonomina (2) bagaimana upaya pemerintah dalam upaya pengembangan obyek wisata Pantai Koguna Kecamatan Lasalimu Selatan Kabupaten Buton. Tujuan penelitian ini (1) untuk mengetahui apakah dengan adanya pengembangan obyek wisata pantai koguna terhadap perekonomian masyarakat Desa Mopaano Kecamatan Lasalimu Selatan Kabupaten Buton (2) untuk mengetahui bagaimana pemerintah dalam pengembangan obyek wisata pantai Koguna terhadap 
pendapatan masyarakat di Desa Mopaano Kecamatan Lasalimu Selatan Kabupaten Buton. Metode pada penelitian ini aadalah kualitatif. Teknik pengumpulan data yaitu observasi, wawancara, dokumentasi. Hasil penelitian dapat disimpulkan bahwa dengan adanya pengembangan obyek wisata ini pendapatan masyarakat meningkat, peningkatan aktifitas masyarakat, adanya penyediaan lapangan pekerjaan, kesejahteraan masyarakat sangat. Kesimpulan pada peneltian ini (1) pengembangan obyek wisata ini dapat berdampak pada perekonomian masyarakat di Desa Mopaano dimana pendapatan yang sebelumnya di bawah Rp.1.000.000, setelah adanya pengembangan ini pendapatan meraka rata-rata di atas Rp.1.000.000. (2) adanya upaya pemerintah untuk melakukan pembangunan di obyek wisata mulai dari perbaikan akses jalan,pembangunan sarana dan prasarana di tempat wisata hingga pemerintah akan memperkenalkan obyek wisata ini ke luar daerah kemudian kemerintah akan membuka jalur transportasi laut dan akan menjadikan kawasan ini sebagai kawasan ekonomi kreatif.

Kata Kunci: Dampak Pengembangan, Obyek Wisata, Perekonomian, Hasil

\section{PENDAHULUAN}

Sektor pariwisata merupakan sektor yang potensial untuk di kembangkan sebagai salah satu sumber pendapatan asli daerah. Usaha memperbesar pendapatan asli daerah, maka program pengembangan dan pendayagunaan sumber daya dan potensi pariwisata daerah di harapkan memberikan sumbangan bagi pembangunan ekonomi.

Secara luas pariwisata di pandang sebagai salah satu kegiatan yang mempunyai multidimensi dari rangkaian suatu proses pembangunan. Pembagunan sektor pariwisata menyangkut aspek sosial budaya, ekonomi, dan politik (Spillane,2011).Hal tersebut sejalan dengan yang tercantum dalam Undang-Undang Nomor 10 tahun 2009 Tentang Kepariwisataan yang menyatakan bahwa, Penyelenggaraan Kepariwisataan ditujukan untuk meningkatkan pendapatan nasional dalam rangka meningkatkan kesejahteraan dan kemakmuran rakyat, memperluas dan memeratakan kesempatan berusaha dan lapangan pekerjaan berusaha dan lapangan kerja, mendorong pembangunan daerah, memperkenalkan dan mendayagunakan obyek dan dayatarik wisata di Indonesia serta memupuk rasacinta tanah air dan mempererat persahabatan antarbangsa.

Pantai Koguna memiliki hamparan pasir putih yang membentang luas sekitar 2 kilometer. Selain pasir putih, keindahan Pantai Koguna ditambah lagi dengan laut yang bersih dan biru. Seluruh keindahan tersebut masih dipadukan dengan pohon cemara yang tumbuh di atas pasir putih. Berdasarkan data dari dinas pariwisata Kabupaten Buton menyebutkan Jumlah pengunjung pada tahun 2018 sebanyak 83.000 orang dan jumlah pengunjung tiap bulan di perkirakan mencapai 500 orang yang notabenyan bukan hanya berasal dari desa mopaano akan tetapi berasal dari luar desa mopaano seperti pengunjung dari kota baubau, wanci, hingga mancanegar terlebih lagi apabila menjelang musim libur ataupun ada kegiatan tahunan di Kabupaten Buton. Kawasan obyek wisata Pantai Koguna tersebut terdapat rawa yang memilik udang yang biasa yang berwarna merah masyarakat di sana menyebutnya udang merah, pada saat air pasang wisatawan dapat menikmati suasana pantai dengan pemandangan pantai yang masih sangat asri dan dapat memberikan ketenangan bagi para wisatawan. Tak hanya memiliki wisata udang merah, wisata pantai koguna juga memiliki wisata batu terbelah yang berada di dalam kawasan obyek wisata pantai koguna.

Hal ini menjadi alasan penting bagi pemerintah Kabupaten Buton untuk mengembangkan wisata pantai koguna menjadi daerah tujuan wisata. Selain itu pemerintah juga memberikan kesempatan kepada masyarakat sekitar untuk melakukan kegiatan usaha dalam kawasan obyek wisata tersebut. Sehingga secara langsung dapat memberikan kontribusinya kepada pendapatan masyarakat setempat dan telah menjadi mata pencaharian bagi para masyarakat yang tidak memiliki pekerjaan atau pengangguran.

Peningkatan atau bertambahnya jumlah pengunjung membuat masyarakat disekitar kasawan pantai koguna memperoleh kesempatan untuk meningkatkan pendapatan melalui kegiatan/usaha yang di lakukan di sekitar kawasan wisata seperti juru parkir, kios, kantin yang menyediakan makanan dan minuman serta keperluan para wisatawan. Kondisi ini menjadi bagian dari upaya masyarakat untuk meningkatkan perekonomian dalam bentuk usaha kecil dengan memanfaatkan pengembangan wisata pantai 
yang di lakukan oleh pemerintah. Adapun pengembangan obyek wisata yang telah ada di Pantai Koguna adalah perbaikan akses jalan menuju pantai, pengadaan fasilitas sarana dan prasarana seperti wc umum, tempat parkir kendaraan, gerbang masuk pantai koguna, pajak retribusi pantai, gazebo.

Pengembangan wisata pantai tidak terlepas dari kehidupan masyarakat dalam hal ini aktifitas masyarakat pesisir yang memiliki mata pencaharian berbeda-beda, ada yang bekerja sebagai pegawai negeri sipil (PNS), nelayan dan sebagainya. Sehubungan dengan adanya pengembangan obyek wisata tersebut maka masyarakat mempunyai mata pencaharian tambahan untuk memperbaiki kehidupan sehari-hari.Sehubungan dengan hal tersebut, maka penulis tertarik untuk melakukan penelitian dengan judul "Dampak Pengembangan Obyek Wisata Pantai Koguna Terhadap Perekonomian Masyarakat Desa Mopaano Kecamatan Lasalimu Selatan Kabupaten Buton”.

\section{METODE PENELITIAN}

\section{Lokasi Penelitian}

Penelitian ini berlokasi di Desa Mopano Kecamatan Lasalimu Selatan Kabupaten Buton dengan mengambil obyek pada salah satu obyek wisata pantai koguna sebagai obyek pengembangan wisata.

\section{Sumber Data Penelitian}

Menurut Moloeng (2001) pencatatan sumber data melalui wawancara atas pengamatan merupakan hasil gabungan dari kgiatan melihat, mendengar, dan bertanya pada penelitian kualitatif kegiatan-kegiatan ini dilakukan secara sadar, terarah dan senantiasa bertujuan untuk memperoleh suatu informasi yang diperlukan. Sumber data yang digunakan dalam penelitian ini yaitu:

1) Data primer merupakan data yang di peroleh langsung dari pihak pengelolan obyek wisata pantai koguna dan masyarakat di sekitar pantai melalui kegiatan wawancara

2) Data sekunder merupakan data yang bersumber dari kantor atau instansi yang terkait yaitu kantor dinas periwisata Kabupaten Buton.

\section{Subyek Penelitian}

Menurut Arikunto (2010) subyek penelian merupakan tempat dimana data untuk variabel penelitian diperoleh. Dalam penelitian ini menggunakan tehnik sampling berupa purposive sampling. Purposive sampling adalah tehnik pengambilan sampel sumber data dengan pertimbangan tertentu. Dalam penelitian ini, peneliti menetapkan 2 informan kunci secara purposive sampling. Penetapan informan secara sengaja dilakukan dengan beberapa pertimbangan yaitu;

1. Tokoh atau aparat desa koguna.

2. Warga masyarakat yang berasal dari desa koguna.

\section{Teknik Pengumpulan Data}

Maryadi dkk (2010) teknik pengumpulan data yang digunakan dalam penelitian kualitatif adalah teknik yang memungkinkan memperoleh data detail dengan waktu yang relative lama. Teknik yang digunakan dalam penelitian ini adalah sebagai berikut:

\section{Observasi}

Menurut Nawawi dan martin (2011), observasi adalah pengamatan dan pencatatan secara sistematis terhadap unsur-unsur yang tampak pada suatu gejala atau gejala-gejala pada obyek penelitian. Berdasarkan pemaparan diatas dapat disimpulkan bahwa observasi adalah suatu metode yang dimana dalam pengumpulan data melalui pengamatan secara langsung terhadap obyek pengamat dan keterlibatan peneliti dalam melihat secara langsung hasil tata ruang yang telah di implementasikan untuk dibandingkangkan antara kenyataan ideal yang ada pada rencana dan kenyataan dilapangan sehingga peneliti mampu mendefinisikan masalah yang terkait dengan perekonominan masyarakat di Desa Koguna Kecamatan Lasalimu Selatan Kabupaten Buton.

\section{Wawancara}

Menurut Sugiono (2010) wawancara diartikan sebagai teknik pengumpulan data apabila peneliti akan melaksanakan studi pendahuluan untuk menemukan permasalahan yang harus diteliti dan juga peneliti ingin mengetahui hal-hal dari responden yang lebih mendalam dengan jumlah responden sedikit. Wawancara yang digunakan dalam penelitian ini dengan mengajukan pertanyaanpertanyaan terstruktur karena peneliti menggunakan pedoman wawancara yang disusun secara sistematis dan lengkap untuk mengumpulkan data yang dicari. 


\section{Dokumentasi}

Menurut Hamidi (2004) dokumentasi adalah suatu informasi yang berasal dari catatan penting baik dari lembaga atau organisasi maupun dari perorangan. Dokumentasi penelitian ini merupakan pengambilan gambar oleh peneliti untuk memperkuat hasi penelitian.

\section{Teknik Analisis Data}

Menurut Moleong (2010), analisis data adalah proses mengorganisasikan dan mengurutkan data kedalam pola, kategori, dan satuan uraian dasar sehingga dapat di temukan tema dan tempat dirumuskan hipotesis kerja seperti yang disarankan oleh data.prosesanalisisdatadibagimenjadi tigatahapyaitu:

\section{Reduksi Data}

Reduksi data merupakan proses pemilihan, pemusatan perhatian pada penyederhanaan, pengabstrakkan dan transformasi data yang muncul dari catatan tertulis di lapangan. Reduksi data merupakan suatu bentuk aplikasi yang meragamkan, mengelompokan, mengarahkan, membuang, yang tidak perlu dan mengorganisir data dengan cara sedemikiaan rupa sehingga dapat di tarik kesimpulan.

\section{Penyajian Data}

Penelitian di sajikan dengan bermodalkan sejumlah asumsi, konsep, definisi dan proposisi, sedangkan dari kepustakaan dengan didasarkan pada data yang berupa referensi sumber lain yang berkaitan dengan penelitian yang berhasil dihimpun, sedangkan data yang berhasil dihimpun akan diolah serta di analisis berdasarkan indikator variabel yang telah diterapkan sebelumnya.

\section{Pengambilan Kesimpulan}

Peneliti melakukan uji kebenaran, kekokohanya dan kecocokan setiap makna yang muncul dari data yang tertuang. Dalam tahap ini data hasil wawancara dan pengamatan serta data-data sekunder dalam penelitian ini di tarik kesimpulannya, maka didapatlah jawaban pertanyaan dari rumusan masalah sehingga dapat dilihat apakah hasil penelitian ini dapat memenuhi tujuan penelitian atau tidak.

\section{HASIL DAN PEMBAHASAN Hasil Penelitian}

\section{Pendapatan Masyarakat}

Menurut Soekartawi (2012) menjelaskan pendapatan akan mempengaruhi banyaknya barang yang dikonsumsikan, bahwa sering kali dijumpai dengan bertambahnya pendapatan, maka barang yang dikonsumsi bukan saja bertambah, tapi juga kualitas barang tersebut ikut menjadi perhatian. Misalnya sebelum adanya penambahan pendapatan beras yang dikonsumsikan adalah kualitas yang kurang baik, akan tetapi setelah adanya penambahan pendapatan maka konsumsi beras menjadi kualitas yang lebih baik.

Dari hasil penelitian di lapangan di peroleh data bahwa pendapatan masyarakat yang berada di desa Mopaano Kecamatan Lasalimu Selatan Kabupaten Buton mengalami peningkatan tiap tahunnya hal ini dikarenakan adanya peluang untuk kerja yang disediakan oleh pemerintah ataupun peluang pekerjaan yang secara pribadi di kelolah oleh masyarakat setempat. Adapun peluang pekerjaan yang disediakan oleh pemerintah misalnya penjaga gerbang, pengelola gazebo, pengelola wc umum. Dari beberapa pekerjaan yang tersediah dapat dilihat besaran pendapatan atau pengasilan yang diperoleh masyarakat yang bekerja di sekitar obyek wisata pantai koguna.

Tabel. 1 Aktifitas Masyarakat Setelah Adanya Pengembangan

\begin{tabular}{clc}
\hline No & \multicolumn{1}{c}{ Aktifitas Baru Setelah Adanya Pengembangan } & Penghasilan Tiap Bulan \\
\hline 1 & Penjual & Rp.500.000-Rp.700.000 \\
2 & Juru Parkir & Rp. 300.000 \\
3 & Penjaga Gerbang & Rp. 400.000 \\
4 & Pengelola Gazebo & Rp. 400.000 \\
5 & Pengelola Wc Umum & Rp. 200.000 \\
6 & Kantor Pusat Informasi & Rp. 200.000
\end{tabular}

Sumber: Analisis Data Primer, 2019.

Berdasarkan tabel di atas dapat di lihat penghasilan dari penjual berkisar antara 
berpenghasilan Rp.400.000, pengelola gazebo memiliki penghasilan Rp.400.000, pengelola wc umum Rp.200.000 dan yang petugas

kantor informasi berpenghasilan Rp.200.000.

Tabel 2. Pendapatan Responden Dalam Sebulan

\begin{tabular}{cccc}
\hline No. & Kelas Interval & Frekuensi & Persentase \\
\hline 1. & Rp. 500.000 -Rp.1.000.000 & 8 & 36.36 \\
2. & Rp. $1.500 .000-$ Rp. 2000.000 & 13 & 59.09 \\
3. & Rp.2.500.000-Rp.3000.000 & 1 & 4.54 \\
\hline & Jumlah & $\mathbf{2 2}$ & $\mathbf{1 0 0}$ \\
\hline
\end{tabular}

Sumber: Analisis Data Primer, 2019.

Dari tabel diatas dapat dijelaskan bahwa responden yang memiliki pendapatan tertinggi yaitu responden yang memiliki pendapatan Rp.1.500.000-Rp.2000.000 sebanyak 13 jiwa/orang dengan persentase $59.09 \%$,yang memiliki pendapatan Rp.500.000-Rp.1000.000 sebanyak 8 orang dengan presentase 36.36 orang/jiwa sedangkan yang memiliki pendapatan Rp.2.500.000-Rp.3.000.000 sebanyak 1 orang/jiwa dengan presentase $4.54 \%$.

\section{Peningkatan Aktivitas Masyarakat}

Aktivitas merupakan segala sesuatu yang sering dilakukan oleh manusia dalam memenuhi segala kebutuhannya. Aktifitas masyarakat akan mengalami peningkatan apabila tersedia lapangan pekerjaan atau adanya peluang untuk melakukan aktifitas baru di sekitar pantai koguna misalnya dengan menjadi penjaga keamanan, menjaga parkiran, menjual disekitar pantai.

Berdasarkan hasil penelitian di lapangan bahwa dengan adanya pengembangan obyek wisata ini masyarakat disana khususnya di Desa Mopaano secara tidak langsung mengalami perubahan dikarenakan adanya Peluang untuk melakukan aktivitas baru yang dilakukan oleh masyarakat di Desa Mopaano, aktifitas baru yang dimaksud seperti menjaga gerbang, menjaga parkiran dan menjaga keaman di sekitar pantai mengingat banyaknya jumlah pengunjung yang datang di lokasi tersebut.

\section{Penyediaan Lapangan Pekerjaan}

Badan Pusat Statistik mendefinisikan tenaga kerja (manpower) sebagai seluruh penduduk dalam usiakerja (15 tahun keatas) yang berpotensi memproduksi barang dan jasa. BPS (Badan Pusat Statistik) membagi tenaga kerja (employed), yaitu:

1. Tenaga kerja penuh

2. Tenaga kerja tidak penuh atau setengah pengangguran

3. Tenaga kerja yang belum bekerja atau sementara tidak bekerja

Penyediaan lapangan pekerjaan sangat berpengaruh terhadap kehidupan masyarakat hal ini dikarenakan dapat meningkatkan pendapatan atau penghasil warga setempat. Adanya lapangan pekerjaan yang cukup dapat membantu perekonomian masyarakat sama halnya dengan di Desa Mopaano dengan adanya pengembangan obyek wisata koguna dapat menyediakan lapangan pekerjaan bagi masyarakat disana warga misalnya dengan menjadi penjaga parkiran memang pekerjaan ini tidak di lakukan tiap hari melainkan tiap hari minggu, akan tetapi ini sangat kondisi ini sangat membantu masyarakat di sana. Adapun aktifitas masyarakat setelah adanya pengembangan dapat di lihat pada tabel ini bawah ini:

Tabel 3. Aktifitas Masyarakat Setelah Adanya Pengembangan

\begin{tabular}{clccc}
\hline No. & \multicolumn{2}{c}{ Aktifitas Baru Setelah Adanya Pengembangan } & Frekuensi & Persentase \\
\hline 1. & Penjual & 6 & 27.27 \\
2. & Juru Parker & 3 & 13.63 \\
3. & Penjaga Gerbang & 3 & 13.63 \\
4. & Pengelola Gazebo & 5 & 23.80 \\
5. & Pengelola Wc Umum & 2 & 9.09 \\
6. & Kantor Pusat Informasi & Jumlah & 2 & 9.09 \\
\hline & & $\mathbf{2 2}$ & $\mathbf{1 0 0}$ \\
\hline
\end{tabular}

Sumber: Analisis Data Primer, 2019. 
Berdasarkan tabel di atas dapat di jelaskan bahwa penjual berjumlah 6 orang dengan persentase $27,27 \%$, juru parkir berjumlah 3 orang dengan persentase $13,63 \%$, kemudian penjaga gerbang berjumlah 3 orang dengan persentase $13,63 \%$, sedangkan pengelola gazebo berjumlah 5 orang dengan $27,27 \%$, sedangkan pengelolah wc umum berjumlah 2 dengan persentase $9,09 \%$, dan kantor pusat informasi berjumlah 2 orang dengan persentase $9,09 \%$.

Dari penelitian dilapangan menunjukan bahwa dengan adanya pengembangan obyek wisata pantai koguna secara tidak langsung dapat menyediakan lapangan pekerjaan bagi masyarakat yang tinggal khususnya dekat dengan objek wisata pantai koguna, misalnya masyarakat yang pada awalnya hanya berjualan dan membuka usaha di dalam desa, akan tetapi semenjak adanya pengelolaan obyek wisata pantai koguna masyarakat diberikan kesempatan untuk membuka lapangan pekerjan baru, seperti berjualan di area pantai, selain itu pemerintah desa juga memberikan kesempatan kepada masyarakat desa untuk mengelola administrasi pantai koguna, misalnya menjadi juru parkir atau menjaga gerbang masuk area pantai. Pengadaan akomodasi seperti gazebo dan wc umum merupakan salah satu bagian dari pengembangan objek wisata pantai koguna, yang mana dengan adanya pengadaan tersebut membuka lapangan pekerjaan bagi masyarakat yang tinggal di sekitar pantai koguna, salah satu contohnya adalah menjadi pengelola gazebo atau wc umum tersebut.

Dari pernyataan di atas dapat disimpulkan bahwa jumlah pengangguran di desa tersebut tidak ada hal ini karena telah adanya penyediaan lapangan pekerjaan yang telah disediakan pemerintah untuk masyarakat disana, selain itu sebagian masyarakatnya pergi merantau ke luar daerah.

\section{Kesejahteraan Masyarakat}

Kesejahteraan adalah sebuah tata
kehidupan dan sosial,material,maupun spiritual yang diikuti dengan rasa keselamatan, kesusilaan danketentraman diri, rumah tangga serta masyarakat lahir dan batin yang memungkinkan setiap warga negara dapat melakukan usaha pemenuhankebutuhan jasmani, rohani dan sosial yang sebaik-baiknya bagi diri sendiri,rumah tangga, serta masyarakat dengan menjunjung tinggi hak-hak asasi(Rambe, 2013).
Ada banyak cara untuk mengukur kesejahteraan seseorang, seperti mengukur pendapan seseorang. Pendapatan seseorang yang diukur nantinya akan berhubungan dengan tingkat kesejahteraan masyarakat sebagaimana yang disebutkan dalam beberapa teori bahwa salah satu indicator dalam mengukur kesejahteraan ekonomi masyarakat adalah dengan melihat besaran pendapatan yang diperoleh. Hubungan antara pertumbuhan ekonomi dengan kesejahteraan masyarakat adalah apabila pertumbuhan ekonomi baik maka tingkat pendapatan masyarakat juga akan meningkat selain itu dari peningkatan pendapatan yang terjadi masyarakat akan mampu memenuhi kebutuhan hidupnya lebih baik. Dengan adanya pengembangan obyek wisata di pantai koguna secara tidak langsung dapat meningkatan tingkat kesejahteraan masyarakat Desa Mopaano. Kesejahteraan menurut Badan Pusat Statistik (2010) adalah suatu kondisi dimanaseluruh kebutuhan jasmani dan rohani dari rumah tangga tersebut dapat dipenuhisesuai dengan tingkat hidup.

Berdasarkan data pendapatan yang diperoleh dari responden terlihat adanya peningkatan yang terjadi setelah adanya pengembangan objek wisata pantai koguna, artinya pengembangan objek wisata pantai koguna memberikan peningkatan kesejahteraan dari segi pendapatan.Berdasarkan hasil penelitian dilapangan bahwa kesejahteraan masyarakat di Desa Mopaano sejak adanya obyek wisata Pantai Koguna mulai mengalami peningkatan misalnya yang tadinya masyarakatnya tidak memiliki pendapatan setelah adanya pengembangan obyek wisata ini masyarakat sudah memiliki pendapatan.

\section{Pembahasan}

Pengembangan adalah suatu usaha menuju ke arah yang lebih baik yang menyebabkan adanya perubahan dan pertumbuhan. Perubahan yang dimaksud bisa dalam arti kualitas dan kuantitas. Secara kualitas berarti meningkatkan daya tarik obyek wisata melalui peningkatan mutu pelayanan, sedangkan secara kuantitas berarti perluasan keanekaragaman obyek wisata serta akomodasi lainnya. Dampak dari Pengembangan yang ada di Pantai Koguna secara tidak langsung dapat meningkatkan pendapatan masyarakat di Desa Mopaano Karena dengan di kembangkannya obyek wisata tersebut masyarakat yang tinggal desa tersebut mendapatkan pekerjaan yang baru atau aktifitas 
baru misalnya dengan penyewaan gazebo, menjual di sekitar pantai. Dengan adanya pengembangan obyek wisata ini dapat meminimalisir pengangguran yang ada Desa Mopaano.Adanya pengembangan wisata pantai maka dampak perekonomian terlihat dari aktivitas masyarakat menunjukan suatu perubahan kearah yang lebih baik, dimana sebelum adanya pengembangan obyek wisata pantai aktifitas yang di lakukan oleh responden sebagian besar adalah Petani, nelayan, wiraswasta, pedagang dan PNS, Namun dengan adanya pengembangan obyek wisata pantai respoonden mendapatkan pekerjaan sampingan (tambahan) untuk menambah pendapatan.

Pengembangan obyek wisata tidak terlepas dari peran Pemerintah baik Dinas terkait dalam hal ini Dinas Pariwisata maupun Pemerintah Desa, peran pemerintah dalam Pengembangan Pantai Koguna sangat berpengaruh terhadap perekonomian masyarakat di Desa Mopaano, hal ini di karenakan dengan adanya pengembangan yang akan membuka peluang kerja sehingga mengakibatkan adanya aktivitas baru dari masyarakat di Desa Mopaano.

Upaya yang telah di lakukan pemerintah dalam pengembangan sarana dan prasarana di pantai koguna misalnya pembangunan gazebo, pembuatan wc umum, pembuatan gerbang masuk, pembuatan kantor pusat informasi, adanya tempat parkir kemudian jalan atau akses ke obyek wisata pantai pantai koguna di perbaiki. Perimerintah juga akan menjadikan kawasan ini sebagai kawasan ekowisata dan pemerintah juga berencana menjadikan kawasan ini sebagai kawasan ekonomi khusus dengan begitu akan mempermudah perekonomian masyarakat disana, Selain perbaikan infrastruktur pemerintah dalam pengembangkan pariwisata juga mempromosikan obyek wisata ini ke luar daerah misalnya pemerintah Kabupaten Buton bekerja sama dengan Pemerintah Kabupaten Wakotobi dalam bidang pariwisata rencana akan buka jalur transportasi laut untuk mempermudah akses ke obyek wisata jadi apabila ada wisatawan yang berkunjung ke pulau hoga atau ke wakotobi akan di arahkan untuk ke pantai Koguna mengingat jaraknya yang tidak terlalu jauh, hal yang sama juga diungkapkan oleh pak armin selaku sekretaris Desa Moopano.

Dengan adanya pengembangan yang disebutkan di atas maka secara tidak langsung dapat meningkatkan aktifitas masyarakat khususnya masyarakat yang tinggal atau yang melalukan aktifitas di pantai, dengan adanya aktifitas baru tersebut maka secara tidak langsung dapat meningkatkan pendapatan masyarakat dengan peningkatnya pendapatan masyarakat maka akan mempengaruhi tingkat kesejahteraan masyarakat di Desa Mopano Kecamatan Lasalimu Selatan. Pendapatan masyarakat mopaano berdasarkan penggolongan (BPS) masih tergolong berpendapatan sedang karena rata-rata pendapatan masyarakat antara Rp.1.500.000- Rp.2.000.000.

\section{PENUTUP}

\section{Kesimpulan}

1. Pengembangan obyek wisata pantai koguna memberikan dampak terhadap aktifitas perekonomian masyarakat, sebelumnya sebagian masyarakatnya bekerja sebagai petani dan nelayan, namun setelah adanya pengembangan obyek wisata aktifitas ekonomi meningkat, dimana dengan adanya pengembangan tersebut masyarakat mendapatkan aktivitas tambahan atau pekerjaan tambahan sebagai pedagang, serta menyediakan jasa berupa fasilitas yang disewakan untuk wisatawan yang berkunjung seperti gazebo, wc umum, tikar. Pengembangan obyek wisata wisata dapat juga berdampak pada kesejahteraan masyarakat di Desa Mopaano, dimana dengan adanya pengembangan di obyek wisata ini jumlah pendapatan masyarakat meningkat yang awalnya pendapatnya di bawah Rp.1.000.000 per bulan namun setelah adanya pengembangan pendapatan masyarakat kini rata-rata di atas Rp.1.000.000. perbulan.

2. Adanya upaya pemerintah untuk melakukan pembangunan di obyek wisata tersebut mulai dari akses jalannya, pembangunan gazebo,wc umum,tempat parkir, kantor pusat informasi, gerbang masuk, hingga pemeritantah berupaya untuk memperkenalkan obyek wisata ini ke daerah luar, selain itu pemerintah juga akan menjadikan kawasan ini sebagai kawasan ekonomi kreatif dan juga adanya rencana untuk membangun atau penyediaan jalur transportasi laut.

\section{Saran}

Berdasarkan simpulan di atas, maka disarankan agar pemerintah daerah setempat khususnya Dinas Pariwisata untuk mengoptimalkan pendidikan dalam pengembangan pariwisata maka dengan itu pemerintah harus membangun pendidikan 
pariwisata, pelatihan pariwisata dan meningkatkan sarana dan prasarana serta fasilitas rekreasi dengan lebih baik lagi di objek wisata pantai koguna, maka masyarakat di harapkan dapat meningkatkan kegiatan usahanya dengan menyediakan berbagai fasilitas rekreasi dan dagangannya dengan demikian dapat meningkatkan aktifitas ekomoni sehingga pendapatnnya meningkat dengan begitu masyarakat dapat merasakan adanya dampak dari pengembangan.

\section{DAFTAR PUSTAKA}

Arikunto, Suharsimi. 2010. Prosedur Penelitian Suatu Pendekatan Praktek. Jakarta: PT Renika Cipta.

Badan Pusat Statistik. 2013. Indikator Penilaian Sosial Eknomi MasyarakatSulawesi Tenggara. https://www.bps.go.id (Diakses 21 Februari 2019).

Badan Pusat Statistika. 2010. Buton Dalam Angka. BPS Provinsi Sulawesi Tenggara. https://butonkab.bps.go.id/publication/ (Diakses 21 Februari 2019)

James, J Spillane. 2011. Ekonomi Pariwisata Sejarah dan Prospeknya. Yogyakarta: Kanisus.
Lexy, J. Moleong. 2010 . Metodelogi Penelitian Kualitatif. Bandung: Remaja Rosdakarya.

Maryadi Dkk .2010 . Pedoman Penulisan Skripsi Fkip . Bp-Fkip Ums . Surakarta

Nawawi, Hadani dan M. Martini .Hadani, 2011. Instrument Penelitian Bidang Sosial. Yogyakarta: Gadja Mada University Press.

Rambe, A. 2013. Alokasi Pengeluaran Rumah Tangga dan Tingkat Kesejahteraan (Kasus di Kecamatan Medan, Kota Sumatra Utara). Thesis. Bogor: Sekolah Pascasarjana IPB,

Sugiono .2010. Metode Penelitian Pendekatan Pendidikan Kualitatif, Kuantitatif dan $R \& D$. Bandung: Alfabeta.

Undang-Undang Nomor 10 Tahun 2019 Tentang Kepariwisataan. https://www.ekowisata.org/uploads/files/U U_10_2009.pdf (Diakses 20 Februari 2019).

Pengelola Jurnal Penelitian Pendidikan Geografi

La Ode Amaluddin

Gedung FKIP Lt.2 Universitas Halu Oleo.

Kampung Bumi Tridarma Anduonohu Kendari93232

Email:amaluddin.75@gmail.com 